\title{
Speaking Self-Efficacy and EFL Student Teachers' Speaking Achievement
}

\author{
Tutik Alawiyah \\ An English Instructor of Mindset English Center in Palembang, South Sumatera \\ tutikalawiyab64@gmail.com
}

\begin{abstract}
This study was to find out the significant correlation between students' speaking self-efficacy and their speaking achievement and to know the significant influence of speaking self-efficacy on their speaking achievement. The population of the study was 470 active students of English Education Study Program of Tarbiyah Faculty and Teaching Sciences at State Islamic University of Raden Fatah Palembang in academic year 2017/2018. The sample of this study was 103 students of all the students in sixth semester chosen by using purposive sampling technique, but there were 96 students participating when the study was conducted. A questionnare was used to measure students' speaking self-efficacy and a speaking test was conducted to know students' speaking achievement. The collected data then were analyzed by using the correlational and regression analysis computerized with SPSS 22. Based on the analysis results, it was found that there was statistically significant positive correlation between self-efficacy and speaking achievement in p-output was 0.00 which was smaller that $0.05(0.00<0.05)$. Besides, the correlational coefficient of the test was .349. Thus, the level of correlation was weak. This study also indicated that students' speaking-self-efficacy influenced their speaking achievement with contribution $12.2 \%$.
\end{abstract}

Keywords: speaking self-efficacy, speaking achievement, student teacher

Manuscript submitted: July 18, 2017

Manuscript revised: December 24, 2017

Accepted for publication: January 4, 2018

\section{Introduction}

English has become one of international languages used by people from all around the world. It is widely accepted as the primary international language, and it is increasingly defined as a basic skill required of every student in every education system (Abrar \& Mukminin, 2016; Habibi, Sofwan, \& Mukminin, 2016; Haryanto \& Mukminin, 2012). The ability to communicate in English can be achieved by mastering 4 language skills and one of which is speaking (Kamil \& Mukminin, 2015; Mukminin, Ali, \& Ashari, 2015; Mukminin, Masbirorotni, Noprival, Sutarno, Arif, \& Maimunah, 2015). English speaking is one of the most important skills to be developed and enhanced as means of effective communication (Morozova, 2013). Speaking depends on the complexity of the information to be communicated (Brown \& Yule, 2001). It will help people who come from different countries to be easier when making communication and to avoid missunderstanding among native or non-native English speakers. In the realm of education, particulary in the teaching and learning process, speaking plays an important role. White (2004) argues that language is an integral part of learning and oral language has a key role in classroom teaching and learning. It means that speaking will help teaching and learning more effective for 
teacher and students. It shows that English speaking ability is very important, not only in work field but also in teaching and learning in the English class.

Nowadays, speaking has been given priority during English teaching and learning process. However, some problems may occur. Teachers and students of Indonesia still have difficulties in spoken language (Mukminin, Muazza, Hustarna, \& Sari, 2015; Mukminin, Ali, \& Ashari, 2015; Mukminin, Masbirorotni, Noprival, Sutarno, Arif, \& Maimunah, 2015). Brown and Yule (2001) state that spoken language production, learning to talk in the foreign language, is often considered being one of the most difficult aspects of language learning for the teacher to help the students with. Sometimes, EFL learners do not feel confident in their speaking performance which ends up poorly. According to Young (1990), speaking class tends to make students feel nervous and anxious. Students in foreign language classroom generally report that speaking in the target language is the most anxiety producing experience (Ozturk and Gurbus, 2014). It is also supported by Horwitz who states that anxiety is "the subjective feeling of tension, apprehension, nervousness, and worry associated with an arousal of the autonomic nervous system" (as cited in Abrar, Mukminin, Habibi, Asyrafi, Makmur, \& Marzulina, 2018, p.131).

The problem is because English is a foreign language so that students rarely practice it in their daily life. Other reason is that students lack of motivation to practice the language in daily conversation that they are too shy in conversation. Actually, there so many reasons that make students difficult in speaking because in Indonesia context, not all of the students during English speaking activities have the courage to speak (Mukminin, Muazza, Hustarna, \& Sari, 2015; Yusuf, Yusuf, Yusuf, \& Nadya, 2017).

For those reasons, the quality of English speaking skill in Indonesia is still not satisfactory. This situation is supported by English First English Proficiency Index (2015) that reported the average level of English language skill in some countries and the data of English speaking skill in Indonesia is in the rank of 32 from 70 participant countries. Based on EF EPI, Indonesia is in medium level (52.91). It indicates that Indonesians' speaking skill is not good enough. To solve those problems, self-efficacy for students must be developed. Bandura (1997) mentions that selfefficacy concerns with someone's perception about capability to create his/her own achievement. Self-efficacy is "people's judgments of their capabilities to organize and execute courses of action required to attain designated types of performances" (Bandura, 1986). Selfefficacy describes individuals' beliefs in their capabilities to exercise control over challenging demands and over their own functioning (Luszczynska, Gutierrez-Dona, \& Schwarzer, 2005) Thus, it can be said that self-efficacy has an important role for students.

Concerning with speaking self-efficacy in relation to their speaking skill, an informal interview with undergraduate EFL students of State Islamic University of Raden Fatah Palembang was conducted, and it was found that some of them enjoyed speaking English, while others did not. They also were not sure to speak because sometimes they did not feel confident with their ability to interact with others. Even though, they had known that self-efficacy could affect their speaking achievement, but they did not know much about their speaking self-efficacy level. The students who had low self-efficacy in speaking reported that they would quickly lose confident and get negative outcome. The information that they gave was not clear and effective.

Regarding the relationship between speaking self-efficacy and speaking perfomance, many studies have been undertaken to investigate those two variables. First, the correlation between self-efficacy belief, language performance and integration among Chinese Immigrant Newcomers was investigated by Dodds (2011), and it was found that there were significant positive correlations between English speaking self-efficacy beliefs and English speaking performance along with English listening self-efficacy beliefs and English performance. Also, Asakereh and Dehghannezhad (2015) found that there was relationship between Iranian EFL students' satisfaction with speaking classes, speaking skills self-efficacy beliefs and speaking skills 
achievement. Hence, it was critically essential to illuminate the correlation between self-efficacy of the students and their speaking achievement.

The previous studies focused on the relationship between self-efficacy beliefs, English performance, and speaking skills achievement. This study focused on the correlation between students' speaking self-efficacy and their speaking achievement. It involved the state students of English Education Study Program of State Islamic University of Raden Fatah Palembang. Therefore, the objectives of this study was to find out if there was significant correlation between speaking self-efficacy and speaking achievement of English Education Study Program Students of State Islamic University of Raden Fatah Palembang and if their speaking self-efficacy influenced ther speaking achivement.

\section{Literature Review}

\section{The concept of speaking}

Speaking has been regarded as one of the important parts in foreign language learning (Fang-peng \& Dong, 2010). Generally, speaking is the ability to express something in a spoken language. It is simply concerning putting ideas into words to make other people grasp the message that is conveyed. In this study, the term "speaking" is one of four language skills related to language teaching and learning (Attamimi, 2014). Thornbury (2007) states that speaking is a speech production that becomes a part of daily activities which involves interaction. It means that speaking is any process in which people share information, idea, and feeling, so, if one able to communicate well, she or he will be able to interact with many people. In assesing students' speaking achievement, there are some aspects should be measured.Those are fluency, pronounciation, grammar, vovabulary, and comprehension. Rozakis (2007) explains that communication can be classified into five categories, they are as follows:

a. Interpersonal communication means communication with ourselves (e.g. evaluate feedback and construct meaning).

b. Interpersonal communication with other people (e.g. talk with one or more people and work as equals).

c. Small group communication means communication with three or more people (e.g. work together to research consensus, state belief as a group, and work with others to solve problems).

d. Public communication means communication with large of group (e.g. share in front of the audience and speakers and receive less feedback).

e. Mass communication means through mass media (e.g. communication through TV, radio, and so on).

\section{Self-efficacy theory}

Self-efficacy theory was articulated in 1995 by Albert Bandura. Self-efficacy is an individual's belief in his or her capacity to execute behaviors necessary to produce specific performance attainments (Bandura, 1995). Self-efficacy beliefs are an important aspect of human motivation and behavior as well as influence the actions that can affect one's life. More simply, self-efficacy is what an individual believes he or she can accomplish using his or her skills under certain circumstances (Snyder \& Lopez, 2007).

Self-efficacy (beliefs about one's ability to accomplish specific tasks) influences the tasks employees choose to learn and the goals they set for themselves. Self-efficacy also affects employees' level of effort and persistence when learning difficult tasks (Lunenburg, 2011). In addition, Lunenburg (2011) argues that self-efficacy has influence over people's ability to learn, their motivation and their performance, as people will often attempt to learn and perform only 
those task for which they believe they will be successful. Along with goal-setting, self-efficacy is one of the most powerful motivational predictors of how well a person will perform at almost any endeavor.

\section{Methodology}

\section{Research design}

This study used correlational research in terms of explanatory to find out the correlation among variables and explained and interpreted the results that may appear. The sample was given questionnaire and test in order to collect the data.

\section{Research site, sampling, and participants}

The population of this study was all active students of English Education Study Program of State Islamic University of Raden Fatah Palembang in the academic year 2017-2018 which consisted of 470 students. The sample was taken by using purposive sampling. It was a nonrandom sampling technique in which the sample was intentionally selected. I took the students who had already taken speaking class (Speaking I, Speaking II and Speaking III and Speaking IV). Nonetheless, most of the eight and ten semester students had already finished all of the lectures in the speaking class and they were working with their theses. Consequently, it was quite difficult to collect the data from them. For this reason, the sixth semester students were selected. As the result, there were about 103 students participating in this study.

\section{Data collection}

Self-efficacy questionnaire and speaking test were used to collect the data. The questionnaire was readymade from Asakereh \& Dehghannezhad (2015). The remaining 28 items were piloted with one hundred Iranian EFL first year undergraduate students majoring in English language. The results of the pilot study indicated that the questionnaire enjoyed acceptable validity, with Kaiser-Meyer-Olkin (KMO) measure of sampling adequacy being 0.71 . Thus, it was a valid and reliable questionnaire.

For the speaking test, I asked three speaking experts from UIN Raden Fatah Palembang to be validators. The result showed that instrument of speaking test could be used in this research. Based on the result of the reliability test using Pearson Product Moment Correlation Coefficient, it showed that there were very strong correlation among them with correlation coefficient .968, $.988, .919$. Therefore, the questionnaire and speaking test were valid and reliable to collect the data.

\section{Data analysis}

Firstly, to anlyze the data in this study, the data from the questionnaire were analyzed to determine students' self-efficacy. Since, there were 28 items, the maximum score was 140 and the minimum score was 28. Students' scores were categorized into self-efficacy level: low (28-64), medioum (65-102), and high (103-140). Secondly, students' speaking perfomance was analyzed by the three raters, those who validated the speaking test, by using speaking rubric from Brown (2004). There were five aspects of the speaking assessment. They were grammar, vocabulary, comprehension, fluency and pronunciation. The scale of each aspect was from one to five. As a result, the highest point of all was 25 and the lowest score is 5 . Since there were three raters, the average score from them determined the students' speaking achievement. Third, a normality test was used to determine whether sample data drawn from a normally distributed population or not. Therefore, I applied Kolmogorov-Smirnov test by using SPSS 22. The data are distributed normally if the $\mathrm{p}$-value is greater than 0.05 ( $\mathrm{p}>0.5$ ). Fourth, test for linearity by using SPSS 22 
was conducted in order to determine whether the data were linear or not. If the p- value (linearity) is less than 0.05 ( $\mathrm{p}$-value $<0.05)$, the data are linear.

Finally, to analyze the data obtained from the questionnaire, and student's speaking achievement test in order to see the correlation and influence between one variable and another variable, Pearson - Product Moment Correlation Coefficient was used. If there was correlation, regression test was conducted to see the influence of students' self-efficacy of their speaking achievement by comparing the score of F-obtain to F-table. If the score of F-obtain was greater than F-table, it means there was influence between speaking self-efficacy toward speaking achievement. To know if independent variable, self-efficacy, influenced or gave contribution to speaking achievement, regression analysis was done.

\section{Findings and Discussion}

\section{Results of students' self-efficacy and their speaking achievement}

The total active students in the sixth semester of English education study program were 103 students, but there were 96 students participating in this study because the others did not attend when this study was conducted. The 28 items of speaking self-efficacay questionnaire were used to investigate the participants' self-efficacy. The result of the questionnaire revealed that the majority of students, 57 out of $96(59.37 \%)$, had medium in self-efficacy and 39 students out of $96(40.63 \%)$ had high self-efficacy. Last but not least, there was no one categorized as low self-efficacy. Furthermore, the descriptive statistical analysis of students' self-efficacy was shown below. The maximum score was 138 , the minimum score was 66 , the mean score was 97.57 , the standard deviation was 13.88., and the range of self-efficacy was 72 . The result of the questionnaire revealed that the majority of students, 57 out of $96(59.37 \%)$, had medium in selfefficacy and as much as 39 students out of 96 (40.63\%), had high self-efficacy. Last but not least, there was no one categorized as low self-efficacy.

Concerning about students' speaking achievement, speaking test was administered. The result showed that 5 students had excellent speaking achievement, 81 students had good speaking achievement, 10 students had average speaking achievement, and there was no students had poor and very poor speaking achievement. In addition, the descriptive statistical analysis of students' speaking achievement was also obtained, and the result showed that the maximum score was 21.67, the lowest score was 11,33 , the mean score was 18.10 , and the standard deviation was 1.84. This mean score indicated that the level of speaking achievement of participants is good.

\section{The results of normality test and linearity test}

In measuring normality test, 1 Sample Kolmogorov-Smirnov is used. For the normality result of the data of students' speaking achievement, the result showed tht the p-output was 0.93 which was higher than 0.05 . Besides, the normality result of the data of students' self-efficacy showed that the p-output was 0.187 which was also higher than 0.05 . Thus, it can be concluded that all of the data were normal. For linearity test, linearity was obtained. If probability result is less than 0.05 , the two variable are linear. Based on the result of linearity test, it was shown that the sigvalue was 0.001 which was below 0.05 indicating that data were linear.

\section{Correlation between students' self efficacy and their speaking achievement}

In this study, Pearson Product Moment Correlation Coefficient was used to seek the significant correlation between students' self-efficacy and their speaking achievement by using speaking self-efficacy questionnaire and speaking test. Regression analysis was also used to find out if students' self-efficacy influenced students' speaking achievement at English Education 
Study Program students of State Islamic University of Raden Fatah Palembang. The result of statistical analyses are presented in Table 3 and Table 4.

Table 1. Correlation between students self-efficacy and their speaking achievement

\begin{tabular}{llll}
\hline & & Speaking & Self_Efficacy \\
\hline Speaking & Pearson Correlation & 1 &, $349^{* *}$ \\
& Sig. (2-tailed) & &, 000 \\
& N & 96 & 96 \\
Self_Efficacy & Pearson Correlation &, $349^{* *}$ & 1 \\
& Sig. (2-tailed) &, 000 & \\
& N & 96 & 96 \\
\hline
\end{tabular}

**. Correlation is significant at the 0.01 level (2-tailed).

Based on the table above, it was found that the p-output was 0.00 which was smaller than 0.05 $(0.00<0.05)$. Therefore, the null hypothesis was rejected and alternative hypothesis was accepted. It indicated that there was statistically significant positive correlation between self-efficacy and speaking achievement. The correlational coefficient of the test was .349 in which based on Johnson and Christensen (2014), the level of correlation was weak.

\section{Influence of students' self-efficacy on their speaking achievement}

Based on statistical analysis, the result indicated that the students' speaking self-efficacy influenced speaking achievement significantly as t-value (3.606) was higher than t-table (1.662) and sig.value (.00) was lower than probability (.05). Therefore, it can be concluded that student's self-efficacy significantly influenced their speaking achievement. The detail result can be seen in Table 2.

Table 2. The regression analysis of students' self-efficacy and speaking achievement

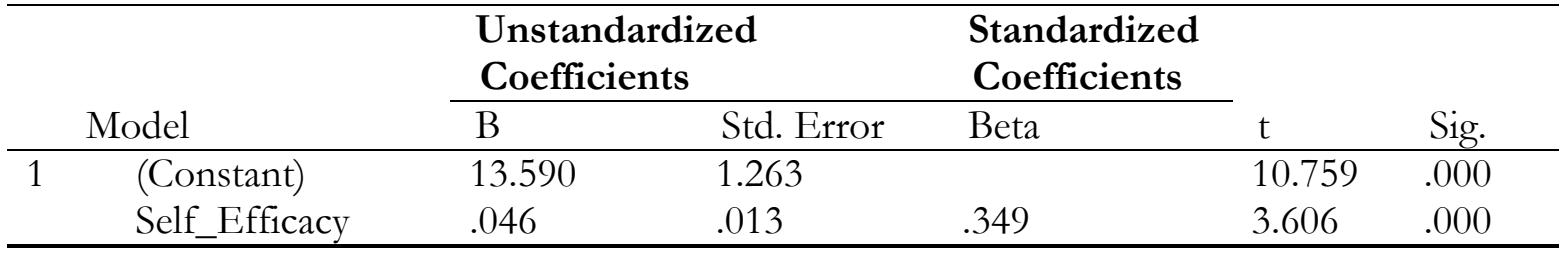

In addition, to know how much students' speaking self-efficacy influenced speaking achievement, R-square was obtained. The result is shown in Table 3.

Table 3. Model summary

\begin{tabular}{lllll}
\hline Model & R & R Square & $\begin{array}{l}\text { Adjusted R } \\
\text { Square }\end{array}$ & $\begin{array}{l}\text { Std. Error of the } \\
\text { Estimate }\end{array}$ \\
\hline 1 & $.349^{\mathrm{a}}$ & .122 & .112 & 1.73417 \\
a. Predictors: (Constant), Self_Efficacy & & \\
\hline
\end{tabular}

The result of the analysis revealed that the R-square was .122. It means that the students' speaking self-efficacy gave significant effect in the level of $12.2 \%$ toward speaking achievement $87.8 \%$ was unexplained factors value. Based on the result of pearson product moment correlation, it was found that there was a positive and a significant correlation between selfefficacy and speaking achievemnt of undergraduate EFL students of English Education study program at State Islamic University of Raden fatah Palembang. It means that self-efficacy had relation to their performance in speaking achievement. The explanation to support this finding is 
that from the beginning of the first semester, the participants had been involved in English speaking practices and assignments. Furthermore, it might be because EFL students of English Education Study Program of UIN are aware of their self-efficacy performance. Students did not compare their perceived competence with their peer's ability in the same area. They assess themselves of how capable they were to accomplish a given task. Tilfarlioglu and Cinkara (2009) explained that it mediates the relationship between knowledge and action. In short, a student having knowledge and skill needed in language learning did not always succeed proficiently to perform it. It was because self-efficacy affects individual's behavior in four ways: selecting choice of behavior, determining how much and how long of the effort, affecting an individual's thought patterns and emotional reaction, and recognizing human as producers than foreteller.

The finding in the study was in line with the study of Asakereh and Dehghannezhad (2015). They found that both student satisfaction with speaking classes and speaking skills selfefficacy beliefs had significant positive correlations with speaking skills achievement, with the latter being stronger. Results of this study showed that students with higher speaking skills selfefficacy are more likely to receive higher scores in speaking skills. Bandura (1986) stated that it can be due to the fact that self-belief in general can help students to participate in tasks, and students with high self-efficacy set higher goals and engage themselves in tasks which require considerable effort, persistence, and interest (Linnenbrink \& Pintrich, 2003; Pajares, 1996). Moreover, self-efficacy beliefs determine the amount of effort, perseverance and resilience individuals spend on an activity, and self-efficacy-beliefs can affect an individual's thought patterns and emotional reactions.

In short, the total contribution of students' self-efficacy and their speaking achievement showed significant correlated and influenced. However the unexplained factors also had contribution on students's sepaking achievemnt. The findings of this study may have some pedagogical implications for lecturers, students, parents and next writers. Finally, this study was successful in investigating the correlation and the influence between students' self-efficacy and their speaking achievement of Students English Education Study Program at State Islamic University of Raden Fatah Palembang.

\section{Conclusions}

From the summary of the answer of the research problems, it was found that the finding received the theory that students' speaking self-efficacy are factors that affect their speaking achievement significantly. The finding indicated that the null hypothesis was rejected while the alternative hypothesis was accepted as the correlation coefficient was .349 and the p-value was .000 which was smaller than $.05(.349<.05)$. It can be implied that there was significant correlation between students' speaking self-efficacy and speaking achievement of EFL students at State Islamic University of Raden Fatah Palembang. Additionally, the linear regression analysis showed that students' self-efficacy $(12.2 \%)$ significantly influenced their speaking achievement. This study may have some pedagogical implications for their foreign language teachers, students, parents, and next writer.

\section{References}

Abrar, M., Mukminin, A., Habibi, A., Asyrafi, F., Makmur, M., \& Marzulina, L. (2018). "If our English isn't a language, what is it?" Indonesian EFL Student Teachers' Challenges Speaking English. The Qualitative Report, 23(1), 129-145. Retrieved from http://nsuworks.nova.edu/tqr/vol23/iss1/9 
Abrar, M., \& Mukminin, A. (2016). International graduate classroom discussion engagement, challenges, and solving-strategies: Stories from Indonesian students in a United Kingdom university. Asia-Pacific Collaborative education Journal, 12(1), 5-20.

Ariesca, \& Marzulina, L. 2016. Teaching reading narrative text by using window notes strategy to the eighth grade students of SMP Muhammadiyah 4 Palembang. Edukasi: Jurnal Pendidikan dan Pengajaran, 3(1), 23-32.

Attamimi, R, A. (2014). Effectiveness of cooperative learning in enhancing speaking skills and attitudes towards learning English. International Journal of Linguistic, 6(4), 1-19.

Asakereh, A., \& Dehghannezhad, M. (2015). Student satisfaction with EFL speaking classes: Relating speaking self-efficacy and skills achievement. Issues in Educational Research, 25(4), 345-363.

Aydogan, H.,Akbarova, A., Dogan, A., Gonen, K., Tuncdemir, E., \& Kerla, M. (2013) I can understand but cannot speak: Language anxiety for oral communication. Global Challenge International Journal of Linguistic and Translation, 1(2), 1-17.

Bandura, A. (1986). Social foundations of thought and action: A social cognitive theory. Englewood Cliffs, NJ: Prentice-Hall.

Bandura, A. (1997). Self-efficacy: The exercise of control. New York, NY: Freeman.

Bandura, A. (2006). Guide for constructing self-efficacy scales: Self-efficacy beliefs of adolescent. Greenwich, CT: Information Age Publishing.

Brown, H. D. (2004). Language assessment: Principles and classroom Practices. New York, NY: Pearson Education.

Brown, H. D. (2004). Teaching by principles: An interactive approach to language pedagogy. San Fransisco, CA: Harper and Row Publisher.

Brown, G., \& Yule, G. (2001). Teaching the spoken language: An approach based on the analysisi of conversational English. Cambridge, UK: Cambridge University Press.

Cherian, J., \& Jacob, J. (2013). Impact of self-efficacy on motivation and performance of employees. International Journal of Business and Management, 8(14), 80-88.

Cohen, L., Manion, L., \& Morrison, K. (6 $6_{\text {th }}$ Eds.). (2007). Research methods in education. New York, NY: Routledge.

Cameron, L. (2001). Teaching language to young learners. Cambrifge, UK: Cambridge University Press.

Creswell, J, W. (2nd Eds.) (2005). Educational research: Planning, conducting, and evaluating quantitative and qualitative research. Upper Saddle River, NJ: Pearson Education.

Crystal, D. (2nd Eds.). (2003). English as global language. Cambridge: Cambridge University Press.

Cubukcu, F. (2008). A study on the correlation between self-efficacy and foreign language learning anxiety. Journal of Theory and Practice in Education, 4(1), 148-158.

Dodds, J. (2011). The correlation between self-efficacy belief, language performance and intergration amongs chinese immigrant newcomers. Minnesota, MN: Hamline University.

Education First. (2015). English proficiency index. Retrieved from http://media.ef.com/ / /media/centralefcom/epi/downloads/full-reports/v5/ef-epi2015-english.pdf.

Fang-peng, G., \& Dong, Y. (2010). A study on college student's anxiety to spoken English. Canadian Social Science, 6(2), 95-101.

Fraenkel, J. R., Wallen, N. E., \& Hyun, H. H. (8th Eds.). (2012). How to evaluate research in education. New York, NY: McGraw-Hill.

Gahungu, O. N., (2007). The relationships among strategy use, self-efficacy, and language ability in language ability in foreign language learners. Retrieved from Northern Arizona University. https://nau.edu/COE/CurriculumInstruction/Admin/ Forms/Gahungu_Dissertation $\underline{\mathrm{PDF} /}$. 
Gunawan, M, A. (1st ed). (2013). Statistik: Untuk penelitian pendidikan. Yogyakarta, Indonesia : Parama Publishing.

Habibi, A., Sofwan, M., \& Mukminin, A. (2016). English teaching implementation in Indonesian pesantrens: teachers'demotivation factors. Indonesian Journal of English Teaching, 5(2), 199-213.

Haryanto, E., \& Mukminin, A. (2012). The Global, the National and the Local goals: English Language Policy Implementation in an Indonesian International Standard School. Excellence in Higher Education Journal, 3(2), 69-78.

Heiman, G. W. (Gth Eds.). (2011). Basic statistics for the behavioral sciences. Belmont, CA: Wadsworth, Cengage Learning.

Hybels, S., \& Weaver, R. L. (2007). Communicating effectively. New York, NY: McGraw Hill.

Johnson, B., \& Christensen, L. (4th Eds.). (2012). Educational research: Quantitative, qualitative, and mixed approaches. Thousand Oaks, CA: SAGE Publications.

Johnson, R. B., \& Christensen, L. B. (2004). Educational research: Quantitative, qualitative, and mixed approaches. Boston, MA: Allyn and Bacon.

Jumana, K. (2016). Self-efficacy and academic performance in English. Imperial Journal of Interdisciplinary Research, 2(2), 79-83.

Kamil, D., \& Mukminin, A. (2015). Indonesian Students' Multicultural Awareness in Homogeneously and Heterogeneously Populated Schools and Multicultural Education Policy. Asia-Pacific Collaborative Education Journal, 11 (1), 29-41.

Khankeh, H., Ranjbar, M., Zavareh, D, K., Boroujeni, A, Z., \& Johansson, E. (2015). Challenges in conducting qualitative reseacrh in health: A conceptual paper. Iranian Journal of Nursing and Midwifery Research, 20(6), 635-641.

Kramsch, C. (1998). Language culture. Oxford, UK: Oxford University Press.

Kubiszyn, N. E., \& Borich, P. R. (4th Eds.). (2007). Inspiring conversation. Brattleboro, VT: Pro Lingua.

Lampert, J, N. (2007). The relationship of self-efficacy and self-concept to academic performance in a college sample: Testing competing models and measures (master's thesis, pacific university). Retrieved from: http://commons.pacificu.edu/spp/86.

Lofgren K. (2013, August 4). Normality test using SPSS: How to check whether data are normally distributed [Video file]. Retrieved from https://www.youtube.com/watch?v=liedOygILn0.

Lunenburg, F, C. (2010). Communication: The process, barriers and improving effectiveness. Journal of Schooling, 1(1), 1-11.

Lunenburg, F, C. (2011). Self-efficacy in the workplace: Implications for motivation and performance. International Journal of Management, Business, and Administration, 14(1), 1-6.

Luszczynska, A., Gutierrez-Dona, B., \& Schwarzer, R. (2005). General self-efficacy in various domains of human functioning: Evidence from five countries. International Journal of Psychology, 40(2), 80-89.

Mahyuddin, R., Elias, H., Cheong, L, S., Muhamad, M, P., Noordin, N., \& Abdullah, M, C. (2006). The relationship betweeen students' self-efficacy and their English language achievement. Journal Pendidikan, 21, 61-71.

Makmur, Ismiyati, Y., Mukminin, A., \& Verawaty. (2016). In search of good student teachers in writing skill: The impact of different task variance on EFL writing proficiency. International Journal of Academic Research in Education, 2 (1). http://dx.doi.org/10.17985/ijare.45901

Mettasari, G. (2013). Self-esteem, achievement motivation, self- efficacy and students' anxiety in speaking. Jurnal Pendidikan dan Pengajaran, 46(2),163-173.

Morozova, Y. (2013). Methods of enhancing speaking skills of elementary level students. Translation Journal, 17(1), 1. 


\section{Edukasi}

Mukminin, A., \& McMahon, B.J. (2013). International Graduate Students' Cross-Cultural Academic Engagement: Stories of Indonesian Doctoral Students on American Campus. The Qualitative Report, 18 (69), 1-19.

Mukminin, A., Ali, Rd. M., \& Fadloan, M.J. (2015). Voices from within: Student teachers' experiences in english academic writing socialization at one Indonesian teacher training program. The Qualitative Report, 20 (9), 1394-1407.

Mukminin, A., Noprival, Masbirorotni, Sutarno, Arif, N., \& Maimunah. (2015). EFL Speaking anxiety among senior high school students and policy recommendations. Journal of Education and Learning, 9(3), 217-225.

Mukminin, A., Muazza, Hustarna, \& Sari, S.R. (2015). Stories from the frontlines: In-service teachers' demotivating factors and policy recommendations. International Journal of Academic Research in Education, 1(2), 40-52. DOI: 10.17985/ijare.56085.

Puriyatno, D. (2010). Paham analisa statistic data dengan SPSS. Yogyakarta, Indonesia: MediaKom.

Radhakrishma, R, B. (2007). Tips for developing and testing questionnaires/instruments. Journal of Extension, 45(1), 1.

Ricards, J.C., \& Schmidt, R. (2002). Longman dictionary of language teaching and applied linguistics. Malaysia: Pearson Education Limited.

Rozakis, M. (2007). The complete idiot's guide to public speaking. Indianapolis: Alpha Books, Inc.

Saeidi, M. \& Farshchi, E, E. (2012). The effect of teaching communication strategies on Iranian EFL learners' speaking self-efficacy in content-based courses. Applied Linguistics Journal, 9(2), 220-238.

Sundari, H., \& Dasmo. (2014). The effect of speaking self-efficacy and gender in speaking activities. Bahasa and Sastra, 14(2), 205-2017.

Schwarzer, R., \& Hallum, S. (2008). Perceived teacher self-efficacy as a predictor of job stress and burnout: Mediational analyses. Applied Psychology: An International Review, 57,152-171.

Thompson, N. (2003). Communication and language: A bandbook of theory and practice. Basingstoke, UK: Palgrave Macmillan.

Thornbury, S. (2007). How to teach speaking. Harlow, UK: Pearson Education Limited.

Tilfarlioglu, F.T., \& Cinkara, E. (2009). Self- efficacy in EFL: differences among proficiency groups and relationship with success. Novitas Royal, 3(2), 129-142.

Yusuf, Q., Yusuf, Y., Yusuf, B., \& Nadya, A. (2017). Skimming and scanning techniques to assist EFL students in understanding English reading texts. Indonesian Research Journal in Education |IRJE |, 1(1), 43-57.

Zimmerman, B, J. (2000). Self-Efficacy: An essential motive to learn. Contemporary Educational Psychology, 25(25), 82-91. 